Article

\title{
Desertification in the Sahel region: a product of climate change or human activities? A case of desert encroachment monitoring in North-Eastern Nigeria using remote sensing techniques
}

\author{
Esther Shupel Ibrahim 1,2,3,4,*, Bello Ahmed ${ }^{5}$, Oludunsin Tunrayo Arodudu ${ }^{4,6}$, Jibril Babayo Abubakar Bitrus ${ }^{1}$, \\ Akila Dang ${ }^{1}$, Mahmoud Ibrahim Mahmoud ${ }^{4,7}$, Halilu Ahmad Shaba ${ }^{8}$ and Sanusi Bello Shamaki ${ }^{9}$ \\ 1 Geography Department, Humboldt-Universität zu Berlin, Unter den Linden 6, 10099 Berlin, Germany. \\ 2 Leibniz Centre for Agricultural Landscape Research, Eberswalder Straße 84, 15374 Müncheberg, Germany. \\ 3 National Centre for Remote Sensing, Jos. Rizek Village Jos Eat LGA, P.M.B. 2136, Jos, Plateau state, National \\ Space Research and Development Agency, Federal Ministry of Science and Technology, Nigeria; bitrusa- \\ kila@yahoo.com(B.A.D); bimasco@gmail.com (J.B). \\ 4 International Centre for Systems thinking, Integrative knowledge and Sustainability in Africa (INTEGRA), \\ Nigeria; oludunsinarodudu@gmail.com (O.T.A). \\ 5 Department of Forestry and Wildlife Management, Federal University Dutse, Jigawa State; bel- \\ lowithu@gmail.com (B.A). \\ 6 Department of Geography, Maynooth University, Ireland. \\ 7 National Oil Spill Detection and Research Agency, Federal Ministry of Environment, Nigeria; salam- \\ mahmoudiii@gmail.com (M.I.M). \\ 8 National Space Research and Development Agency, Federal Ministry of Science and Technology, Nigeria; \\ drhalilu@yahoo.com (H.A.S). \\ 9 Department of Forestry and Environment, Usmanu Dan Fodiyo University Sokoto; san- \\ usi.shamaki@udusok.edu.ng (S.B.S). \\ * Correspondence: esther.shupel.ibrahim@hu-berlin.de, +49 1789772129
}

\begin{abstract}
In Nigeria, desertification has become one of the most pronounced ecological disasters, with the impacts mostly affecting eleven frontline States. This has been attributed to a range of both natural and man-made factors. This study applied a remote sensing-based change detection and indicator analysis to explore land use/land cover changes and detect major conversions from ecologically active land covers to sand dunes. Results indicate that areas covered by sand dunes (a major indicator of desertification) have doubled over the 25 years under consideration (1990 to 2015). Although about $0.71 \mathrm{~km}^{2}$ of dunes have been converted to vegetation, indicative of the success of various international, national, local, and individual afforestation efforts, conversely about 10.1 $\mathrm{km}^{2}$ of vegetation were converted to sand dunes, implying around 14 times more deforestation compared to afforestation. Juxtaposing the progression of sand dune with climate records of the study area and examining the relationship between indicators of climate change and desertification suggested a mismatch between both processes as increasing rainfall and lower temperatures observed in 1994, 2005, 2012, and 2014 did not translated into positive feedbacks for desertification in the study area. On average, our results reveal that sand dune is progressing at a mean annual rate of about $15.2 \mathrm{~km}^{2}$ in the study area. Based on this study's land cover change, trend and conversion assessment, visual reconciliation of climate records with land cover data, statistical analysis, observations from ground-truthing, as well as previous literature, it can be inferred that desertification in Nigeria is less a function of climate change, but more a product of human activities driven by poverty, population growth and failed government policies. Further projections by this study also reveal a high probability of more farmlands being converted to sand dunes by the year 2030 and 2045 if current practices prevail.
\end{abstract}

Keywords: Keywords: Climate change; Land cover; Land use; Conversion; Sand dunes; Environment; Degradation; Poverty. 


\section{Introduction}

Globally, about $41 \%$ of the earth's surface has been engulfed by aridity [1], and more than 2 billion people are reported to reside in these areas [2]. The global demography of people living in extreme poverty corresponds with people living under harsh conditions in arid regions especially in developing nations [3]. Extreme poverty in arid areas can be attributed to an interplay of forces including unfavorable agro-climatic conditions, absence of basic amenities and infrastructures, low level of technological development, overpopulation, and so on [4,5]. Desertification aggravates poverty and further expose inhabitants of arid communities to discomfort by limiting their adaptability to harsh environmental conditions. The Sahara Desert is encroaching southwards at a reported rate of 5-6 $\mathrm{km}$ per year [6,7], and 24-48 km per year [8,9]. Previous research attributes this primarily to a range of natural and man-made factors. The factors include climate change, overgrazing, deforestation, urbanization, bush burning, extensive cultivation, marginal land cultivation, mining, changing land use patterns, excessive application of inorganic fertilizers and agro-chemicals, poverty, etc. $[10,11]$. These primary factors are however indirectly driven by several other elements namely population pressure, socio-economic policies, international trade, as well as geomorphological and climate-related processes [12].

Desertification in the Sahelian region of Nigeria sadly conforms to the global extreme poverty stereotype. Desert features now account for approximately 580, $841 \mathrm{~km}^{2}$ of Nigeria's landmass [13], and accounting for up to $63.8 \%$ of the country's landmass. About 30 million people (17\% of the national population) are affected by desertification in Nigeria [12]. About 15 out of 36 States in Nigeria are affected at different levels of severity. It is however more pronounced in 11 States often referred to as the "frontline States". They include Bauchi, Borno, Gombe, Kano, Katsina, Kaduna, Kebbi, Jigawa, Sokoto, Zamfara, and Yobe States. These States share a border with the Sahelian-Saharan zone of the Niger Republic, which is one of the world's most sensitive ecosystems [12]. Desertification effects is already trending downwards towards the Southern parts of Nigeria at a rate of 0.6 $\mathrm{km}$ per annum, engulfing about 351,000 ha of cropland and rangeland each year [14, 15]. This has resulted in catastrophic consequences to affected human, animal, and plant populations in a variety of ways. Its impacts include forced human migrations, increased erosion, alteration of geochemical composition of soils, surface and ground water depletion, biodiversity loss and species extinction, reduced agricultural yields, higher unemployment and rural poverty rates, as well as rise in social vices and civil conflicts (e.g. kidnapping, armed robbery, religious extremism, insurgency, land/territory grabbing etc.; [16]).

Even though over the years there has been diverse international, national and local efforts and policies to control desertification in Nigeria, its impact persists and threatens the attainment of food security and other important sustainable development goals in the affected States. Regrettably, the affected areas coincide with some of the nation's food baskets i.e. areas that produce and supply high volumes of crops and livestock. A significant proportion of staple food crops like beans, soya beans, tomato, groundnuts, cotton, wheat, rice, melon, pepper, onions etc., as well as animal food products derived from cattle, sheep, and goats are mostly produced in these areas. Expansion of desertification activities in Nigeria can therefore further lead to acute food insecurity, as well as other associated societal problems if not reversed [17]. Despite the far-reaching impacts of desertification globally, there are still limited scientific efforts to assess, monitor, and predict its progression and impacts with precision [18]. The need for timely and precise monitoring and detection of degradation processes is essential for combating aridity. 
Most desert estimates are still on a global scale [19]. There is therefore an urgent need for local and regional scientific research that provides accessible and accurate measurements of the extent of land degradation to drive informed policies [20,21]. Land degradation is a temporal phenomenon, therefore monitoring and developing appropriate intervention mechanisms to tackle land degradation requires robust and frequent repetitive measurements [22]. Remote sensing techniques have been deployed for repetitive measurements aimed at monitoring land degradation because it provides near accurate spatial and temporal measurements of the earth surface [23, 24]. Previous remote sensing-based land degradation detection and monitoring methods focused on the use of land cover time slices to monitor the distribution of desertification or the use of vegetative indices or a combination of both [25 - 28]. Also, advanced vulnerability assessment and modelling techniques have also evolved. These methods provide a map and predict areas under the risk of desertification using complex desertification models, remote sensing data, climate records, and other aridity indices [29 - 32]. Despite this, only few scientific efforts exist in the Nigerian context, with respect to assessing and estimating desert areas using remote sensing and Geographic Information System (GIS) techniques and models [5, 33 - 35]. The focus of most of these previous studies was on the assessment of the general time slices (i.e. intervals) of historic land cover change, and the measurement of the rate and impact of sand dune development. There were however no efforts to assess the causes and drivers of desertification in the Nigerian context. To tackle desertification headlong in the Sahel region, there is need for more precise and timely data on land cover conversions, more accurate predictions of future land cover conversions based on observed rates and measured impacts, as well as an evaluation of the causes and drivers of desertification. As noted by Titiola, [36], effective action aimed at combating desertification and its associated environmental and socio-economic impacts will require the use of precise data and information on its causes, rates, and impacts. Consequently, the main objective of this paper is to explore a more advanced remote sensing-based change detection approach that can assess the causes, rates, and impacts of desertification, and also guide the predictions of future sand dune development patterns. The remote sensing-based change detection approach adopted by this study did not only examine the land cover conversion trends, rates, and impacts, it detected major land cover conversions from and to sand dunes, provided insights into and substantiating the historical causes and major drivers of desertification, while also predicting future sand dune development patterns.

\section{Materials and Methods}

\subsection{Study Area}

The study area is the Northern parts of Yobe State located in the North-Eastern region of Nigeria, it is one of the areas most affected by desertification in Nigeria [5,33]. The area covers Yunusari and Yusufari Local Government Areas (LGAs) in the Northern part of Yobe State and lies between longitude $11.75^{\circ} \mathrm{N}$ and latitude $11.96^{\circ} \mathrm{E}$. With an estimated population of 2, 321, 339 people, Yobe State shares local boundaries with Borno, Jigawa, Bauchi, and Gombe States, as well as an international border with the Republic of Niger to the North [11]. All its neighbouring States are very active desertification sites, except Bauchi State, with minor desertification influence. Yobe State has 17 LGAs which are all associated with severe cases of dune formation [5,33]. The most severe cases are found in the northernmost parts of Yobe State at Yunusari and Yusufari Local Government areas, hence our choice of the two LGAs as case study areas (Figure 1). The major economic activities of the local people include farming, fishing, and livestock production (for meat and dairy); this employs over $80 \%$ of the population and constitutes their major source of income [36, 37]. 


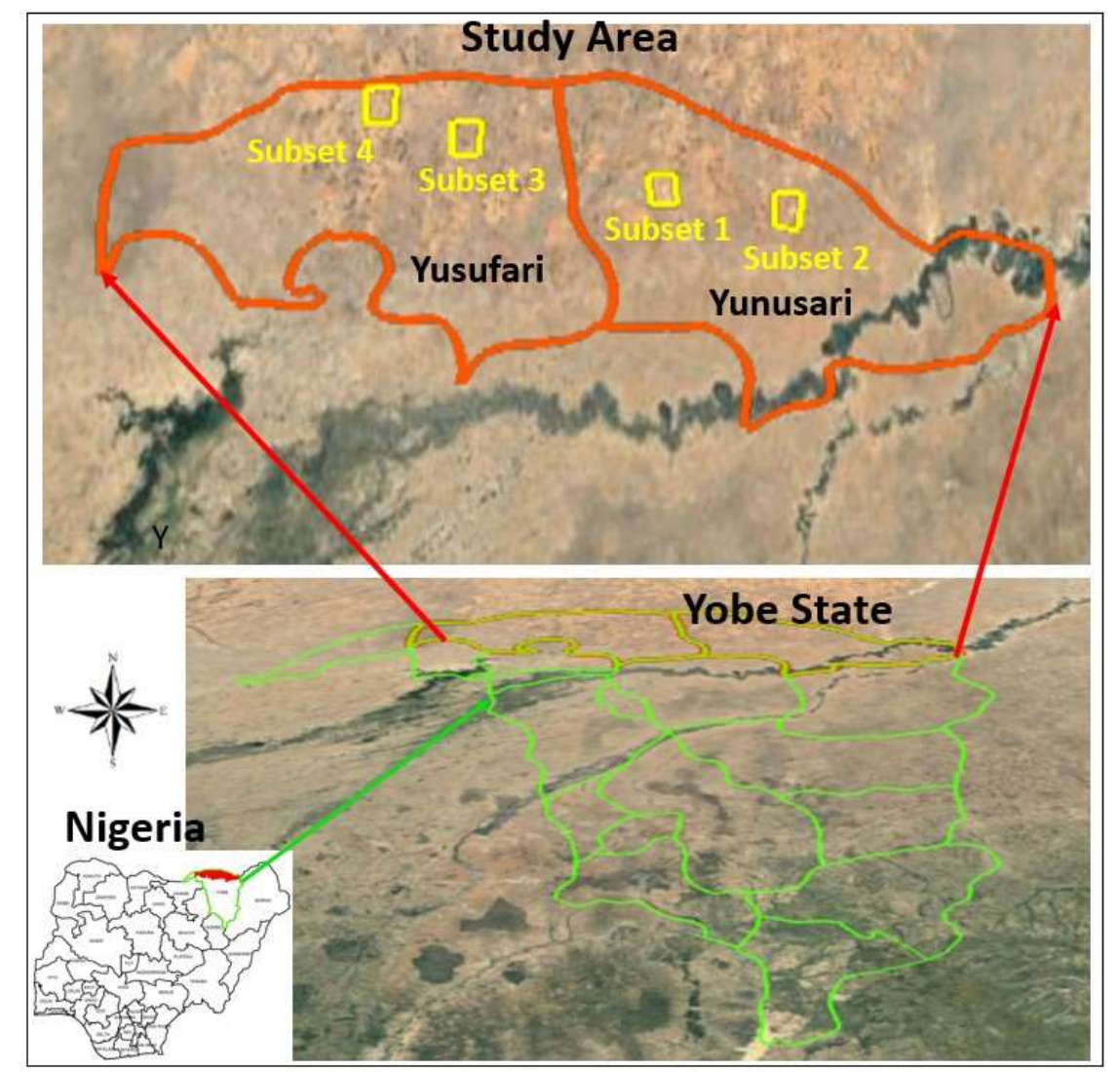

Figure 1: Nigerian map illustrating the position of the study, with google earth satellite data capturing the case study area. The boxes illustrate the location of different subsets used in the results to show sand dunes progression in the study area in (figure 5).

The mean temperature of the study area is about $37^{\circ} \mathrm{C}$, with maximum temperatures of about $42^{\circ} \mathrm{C}$ usually experienced in April, and minimum temperatures of about $30^{\circ} \mathrm{C}$ recorded in December [5]. There is also variability in rainfall patterns, rainfall lasts for about 120 days in Northern Yobe (our study area included) and more than 140 days in the Southern part of the State [33]. This gives rise to two distinct vegetation zones (Figure 1), the case study area is covered by Sahel vegetation to the North and the Southern part covered by Sudan Savannah. The major types of natural vegetation are predominantly scattered Acacia spp., silk cotton, date Palm, baobab trees and short grasses [12]. Most of the soils in the Yobe State are derived from drift silt clay or clayey materials which vary in textural characteristics [14]. The profile of the soils is poorly developed, with low water retention capacity, which makes it easily erodible by the wind. The geological composition is predominantly crystalline and sedimentary rocks underlain by basement complex rocks [5].

\subsection{Data and pre-processing}

Remote sensing approach is used in this study to examine major land cover changes/conversions from and to sand dunes using information from satellite imageries covering the study area. Landsat TM (1990), Landsat ETM (2000), NigeriaSat-1 (2010), and NigeriaSat-X (2015) were the satellite images used for the analysis. Radiometric, atmospheric and geometric corrections were carried out to improve data quality. NigeriaSat-1 $(32 \mathrm{~m})$ and NigeriaSat $-\mathrm{X}(22 \mathrm{~m})$ data were resampled to $30 \mathrm{~m}$ (Landsat data resolution) for spatial consistency and overlay purposes.

\subsection{The Generation of Reference Data}


Field data collection in regions such as our study area are reported to be expensive and tedious and likewise risky as they fall within some of the world's insecure regions [38, 39]. In the recent past, studies are focused on generating training and reference data from auxiliary sources to reduce tedious and expensive field word [ $40-43]$. They have reported significant successes in generating digital and un-orthodox reference data. Commonly google earth image is used for generating reference samples [40, 43, 44]. Studies have reported the capability of auxiliary (secondary) data for training and validating maps as a crucial tool in the development and interpretation of remote sensing data especially in countries like Nigeria where field work is becoming increasingly risky, aggravated by security challenges. We hereby test the capability of axillary data sets for training and validation of land cover classification of this heterogenous landscape in Nigeria using google earth for 2000 and 2010, while we collected field data for the 2015-time stamp.

\subsection{Land cover Mapping and Accuracy Assessment}

Land cover maps of the study area were produced from these satellite imageries using conventional supervised classification method and maximum likelihood algorithm [45 - 48] and recommended for Sub Sahara Africa [42]. This method uses sufficient training data to prevent skewed dimensionality, while also enabling the production of relatively fast and robust classification results [49]. The land cover classes mapped for the study area include wetland and oasis, farmland, built-up, bare land/Sand dunes, and vegetation. The 2010 land cover map (produced from NigeriaSat-2 satellite imagery) was validated using sample points generated from high-resolution data (Google earth). A total of 170 sample points was extracted across all the classified classes to perform the accuracy assessment and an accuracy of $89 \%$ was achieved. For the 2015 land cover map, we conducted fieldwork in the year 2016 for this validation using the good practice methods proposed by Olofsson et al, [50]. A total of 308 points were collected from the field and the distributions of the random samples are shown in table 1 . An accuracy of $81 \%$ was achieved for the 2015 land cover map (See table 1). We assumed that the earlier land cover maps (1990 and 2000) had levels of accuracy close to the last two (2010 and 2015) because the same methods and algorithms were used to produce them.

Table 1: A cross description of 2015 accuracy assessment

\begin{tabular}{|c|c|c|c|c|c|c|c|c|}
\hline Land cover & $\begin{array}{c}\text { Bare surface/ } \\
\text { sand dunes }\end{array}$ & Built-up & Farmland & Vegetation & $\begin{array}{l}\text { Oasis/ } \\
\text { Wetlands }\end{array}$ & Total & $\begin{array}{l}\text { User's } \\
\text { accuracy }\end{array}$ & $\begin{array}{l}\text { Commission } \\
\text { Error }\end{array}$ \\
\hline $\begin{array}{l}\text { Bare surface/ } \\
\text { sand dunes }\end{array}$ & & 4 & 5 & 0 & 0 & 60 & 0.85 & 0.15 \\
\hline Built-up & 0 & 34 & 1 & 0 & 0 & 35 & 0.97 & 0.03 \\
\hline Farmland & 4 & 2 & 94 & 2 & 2 & 104 & 0.90 & 0.10 \\
\hline Vegetation & 0 & 1 & 2 & 41 & 4 & 48 & 0.85 & 0.15 \\
\hline Oasis/ Wetlands & 1 & 1 & 2 & 4 & 53 & 61 & 0.87 & 0.13 \\
\hline $\begin{array}{l}\text { Producer's } \\
\text { accuracy }\end{array}$ & 0.75 & 0.94 & 0.84 & 0.76 & 0.87 & & & \\
\hline
\end{tabular}




$\begin{array}{llllll}\text { Ommission } & 0.25 & 0.06 & 0.16 & 0.24 & 0.13\end{array}$

\section{Error}

Overall accuracy $\quad 0.81(81 \%)$

\subsection{Time Series Assessments and Projections}

Land cover change trends were assessed by performing cross analyses. The losses and gains in each land cover type were estimated. First, the trend assessment began by crossing the land cover map of 1990 and that of 2015 to ascertain the total extent and trend of changes across the land cover classes over the 25 years period of study. Similarly, continuous changes were tracked over time between 1990 and 2000, 2000 and 2010, 2010 and 2015.

The results of the land cover change analysis, was used to run a land cover probabilistic prediction to project future land cover changes based on historical conversions between 1990 and 2015. Land cover probabilistic prediction was applied using a simple cellular automata algorithm - Markovian transition estimator [51 - 54] incorporated in the Idrisi Selva Software package [55]. First, the rate of change between the 1990 and 2000 land cover maps was used to predict 2015 land cover map characteristics. To validate the accuracy of the projections and calibrate the land cover prediction model, the prediction map (predicted 2015 land cover map) was correlated with the initial classified 2015 land cover map (the observed 2015 land cover map; [56, 57]). A significant correlation coefficient (R-value) of 0.79 was obtained from the overlay operation. The obtained significant correlation coefficient is indicative of the reliability of future projections based on the observed land conversion rates. It is, therefore, safe to assume that the accuracy of forecasted projections is reliable and therefore acceptable for planning and policy purposes [56, 57]. Following this, further extrapolations/projections for sand dune expansion for the years 2030 and 2045 were carried out, based on recent trend rates between 2010 and 2015.

\subsection{Climate Change and Landcover Conversions}

Finally, we compared climate records with land use/cover indicators and also ran simple linear regression models to evaluate the strength of relationships or associations between climate change and desertification processes in the northern area of Yobe State Nigeria. Climate records were obtained from Nigerian Meteorological Agency (NIMET) for Nguru which is the weather station nearest to the study area. The indicators of climate change applied for examining the relationship between climate change and desertification activities by this study are climatic parameters such as mean annual temperature and average annual rainfall amounts of the period investigated (i.e. 1990, 2000, 2010, 2015). On the other hand, the indicators of desertification processes adopted for assessing the association between climate change and desertification are change in land cover area coverage of vegetation, sand dunes, as well as oasis and wetland, over the 25-year period considered. 


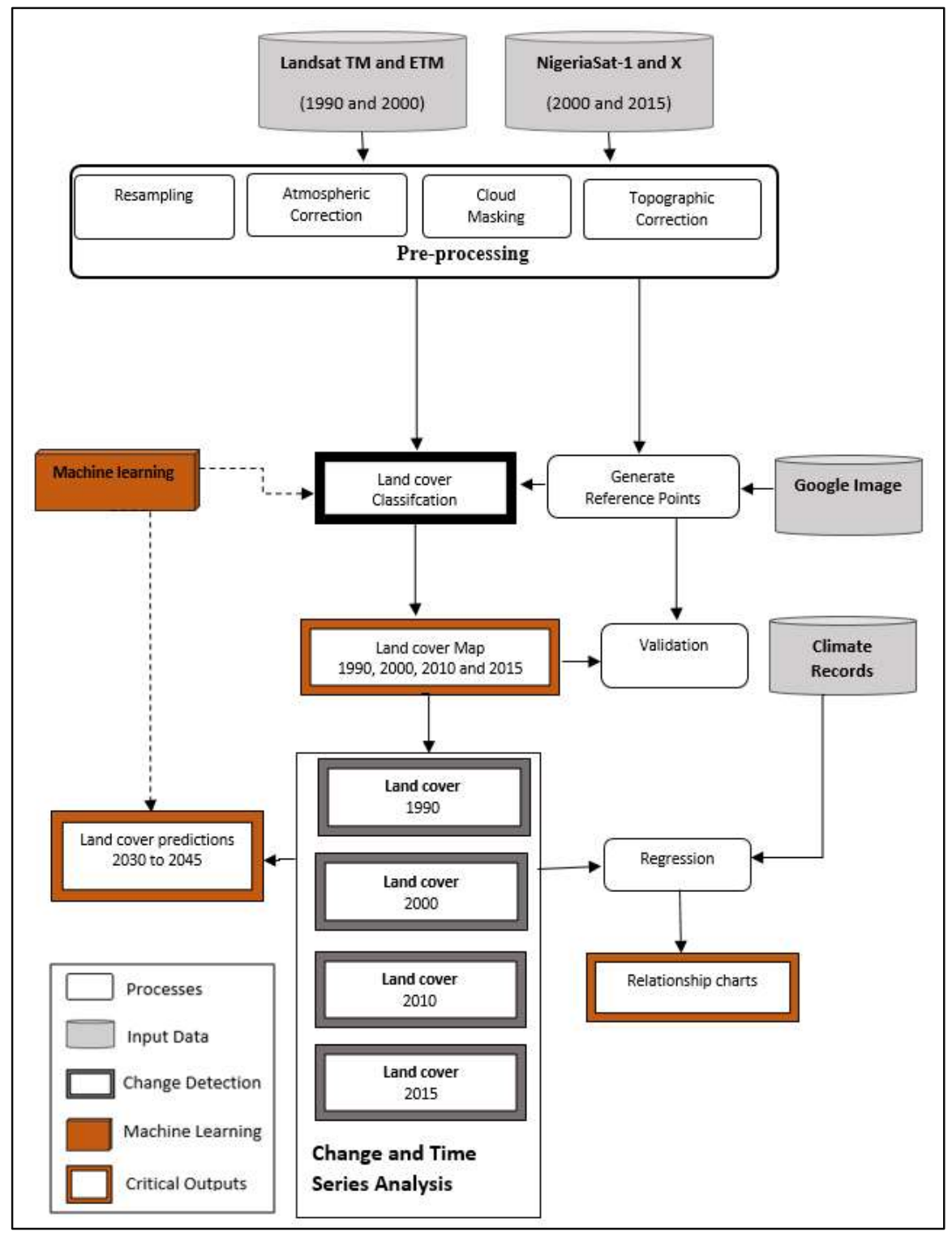

Figure 2. Methodological flow chart.

\section{Results}

\subsection{Land cover changes from 1990 to 2015}

The start year show a low concentration of built-up areas. Buildings and tarmacs covered only 2,519 ha of the landmass i.e. $0.3 \%$ of the total area (Table 2). Land cover map of subsequent years shows a consistent progression in the number of buildings through the time slices. By the year 2015, the built-up areas had increased drastically to about 7,893 ha, which is about $1 \%$ of the total land area (Table 2, Figure 3 and Figure 4 ). The rate of built-up expansion however slowed down between 2010 and 2015. The reverse was the case for vegetation. There was a steady decrease in vegetation throughout the time slices examined. In 1990, vegetation occupied about $11.9 \%$ of the total area, with about 92, 126 ha. This reduced to 75,409 ha which is about $9.7 \%$ of total land coverage in 2000 . There 
was even a further decrease in 2010 and 2015, with 69, 120 ha in 2010, and only 28, 143 ha in 2015 , representing $8.9 \%$ and $3.6 \%$ of total land respectively (Table 1, Figure 3 and Figure 4).

A similar pattern of decline was observed for the wetland and oasis land cover class. In 1990, the wetlands and water oasis covered a total area of 56,563 ha (about $7.3 \%$ of the total area) (Table 2). Unexpectedly, this had increased by the year 2000 to about 57, 110 ha (about $7.4 \%$ of the total area). Nevertheless, there was a decline in 2010 and 2015. By the year 2015 , wetland and oasis occupied 46,857 ha, representing about $6.1 \%$ of total land.
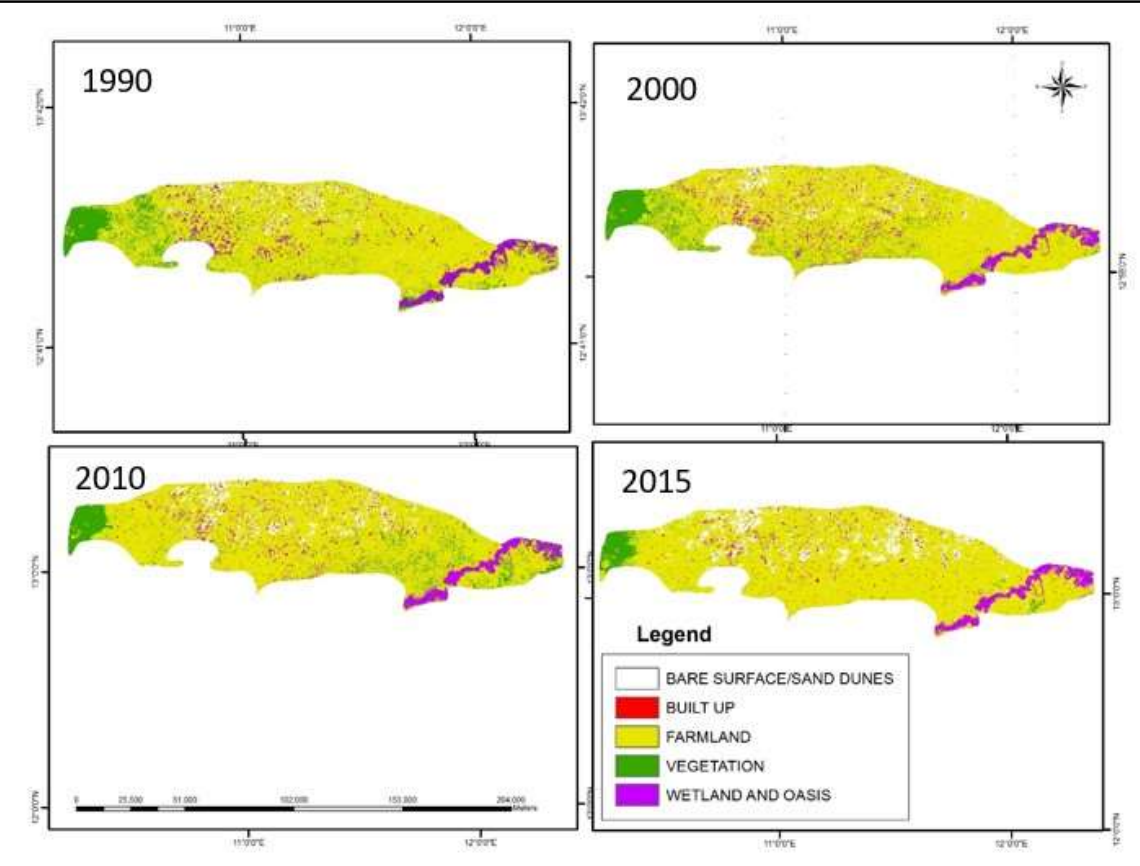

Figure 3: Land Cover Maps Showing Change in Land Cover of Yusufari and Yunusari LGAs over 25 years

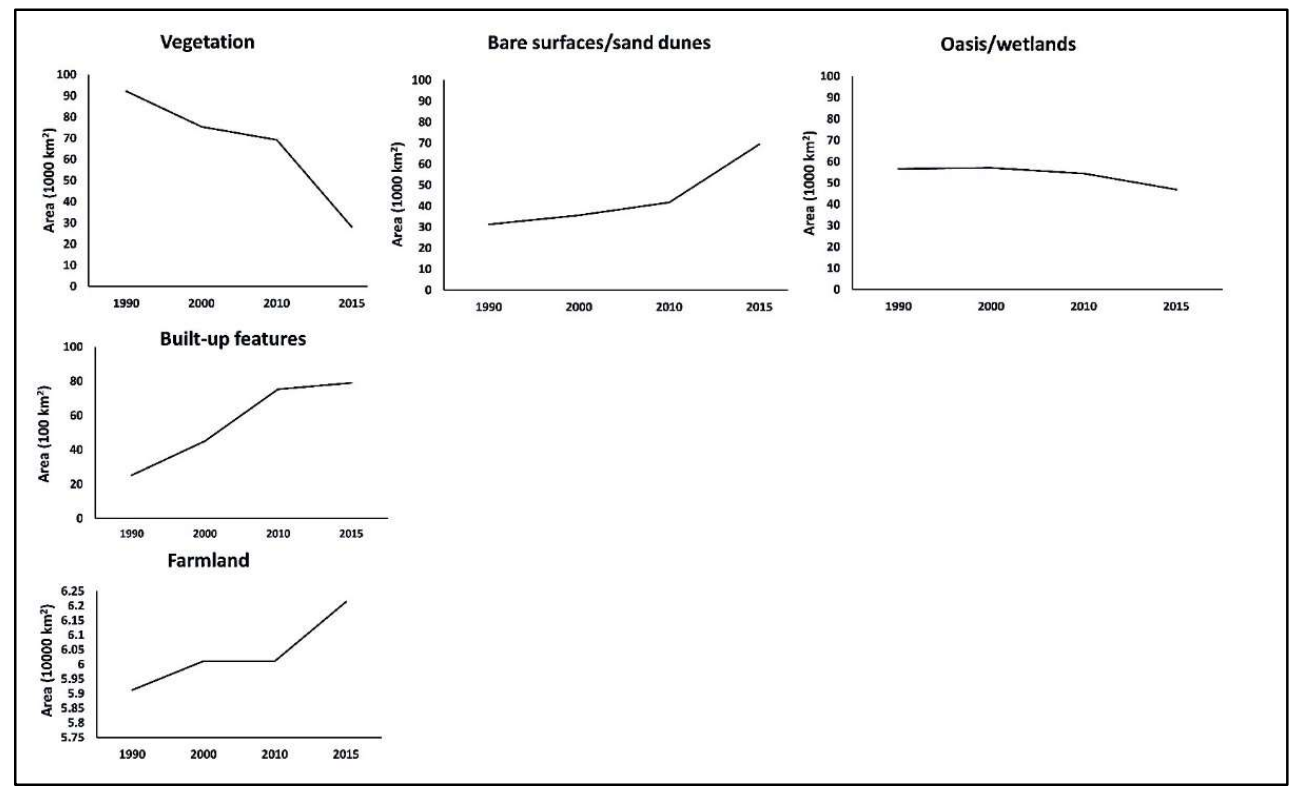

Figure 4: Land cover change trend from 1990 to 2015 
Table 2: Land cover changes from 1990 to 2015

Farmland remains the dominant land cover in the study area. It has consistently increased throughout the study period. In 1990, the farmland occupied about 591, 175 ha (76\% of the total coverage of the two LGAs). This progressed steadily to 621,410 ha by the year 2015, occupying $80.3 \%$ of the total land coverage (Table 2). Also observed was a substantial advancement in sand dune features in the study area. Figure 5 shows the various degree of sand dune progression in different locations across the study area (location of subsets in the study area are shown in figure 1). The coverage of sand dunes in 1990 was 31,369 ha, occupying only about $4.1 \%$ of the total area. This slightly increased within the next ten years to 35,663 ha which is about $4.6 \%$ of the total landmass. Unexpectedly, there was a major increase over the second decade (2000-2010) when about 41, 732 ha of land (about 5.4\% of land area) was covered by sand dunes (Table 1, Figure 2 and Figure 3). More surprizing, the progression over the next five years (2010-2015) almost doubled, with about 69,462 ha of land (up to about $9 \%$ of the total landmass) occupied by sand dunes. On average, our results reveal that sand dune in the study area is progressing at a mean annual rate of 1,524 ha (i.e $15.2 \mathrm{~km}^{2}$ ).

\begin{tabular}{|c|c|c|c|c|c|c|c|c|}
\hline Land cover & $\begin{array}{l}1990 \\
\text { (ha) }\end{array}$ & $\%$ & $\begin{array}{l}2000 \\
\text { (ha) }\end{array}$ & $\% \quad 2$ & $\begin{array}{r}2010 \\
\text { (ha) }\end{array}$ & $\%$ & $\begin{array}{l}2015 \\
\text { (ha) }\end{array}$ & $\%$ \\
\hline $\begin{array}{l}\text { Bare Surface/ } \\
\text { sand dunes }\end{array}$ & 31368.5 & 4.1 & 35663 & 4.6 & 41732 & 5.4 & 69462 & 9 \\
\hline Built up & 2519.8 & 0.3 & 4512.4 & 0.6 & 7527 & 1 & 7893 & 1 \\
\hline Farmland & 591175 & 76.4 & 601112 & 77.7 & 601048 & 77.7 & 621411 & 80.3 \\
\hline Vegetation & 92126 & 11.9 & 75409 & 9.7 & 69120 & 8.9 & 28143 & 3.6 \\
\hline Oasis/wetlands & 56563 & 7.3 & 57110 & 7.4 & 54330 & 7 & 46857 & 6.1 \\
\hline Total & 773752 & 100 & 773806 & 100 & 773757 & 100 & 773766 & 100 \\
\hline
\end{tabular}




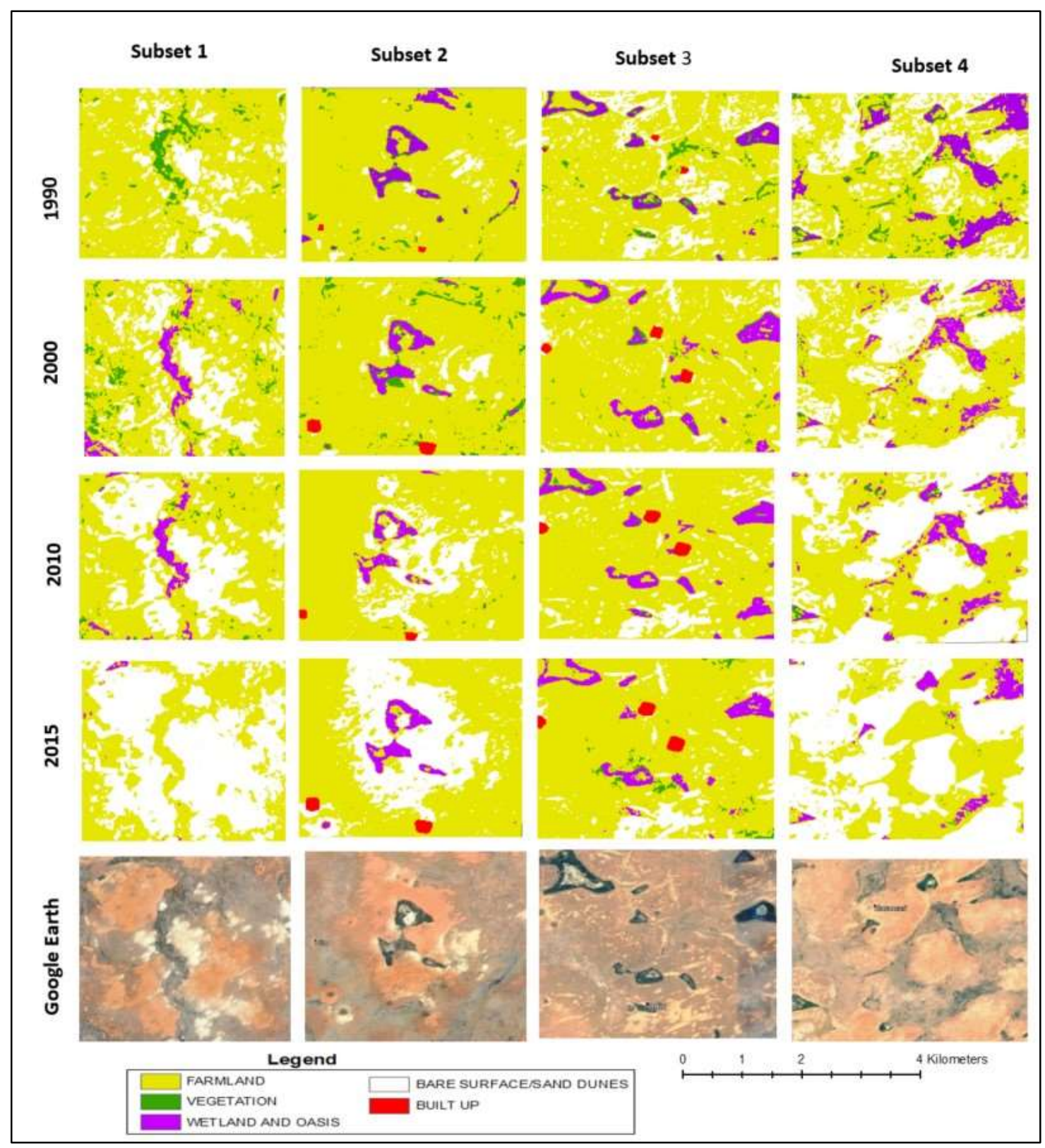

Figure 5: Subsets of sand dune progression in Yusufari and Yunusari LGAs over a 25-year period (see location of subsets in the study area map - shown in figure 1) 


\subsection{Land cover conversions from 1990 to 2015}

The largest conversion of land cover within the 25-year study period was from vegetated land to farmlands (about 62, 411 ha; Table 3 and figure 6). Only 394 ha of vegetated land was converted to built-up. About 331, 412 ha of wetland and oasis have remained unaffected over the study period. While 996 ha of wetlands and oasis were converted to vegetation. Another noteworthy conversion is 17,270 ha of sand dunes to farming. Only 0.2 ha of land has been converted from built-up to sand dunes.

Within the 25-year study period, 519, 371 ha remained consistently farmlands. 21, 782 ha of vegetation and 33, 142 ha of wetland and oasis also did not undergo a change in nature or characteristics. 2,419 ha remained built-up, while 13,656 ha was consistently sand dunes (Table 3 and Figure 6). Likewise, about 54,455 ha of land is converted from farmland to sand dunes and 72 ha of sand dunes converted to vegetation. Conversely, 1,013 ha of vegetation were also converted to sand dunes, implying that there was more deforestation compared to afforestation.
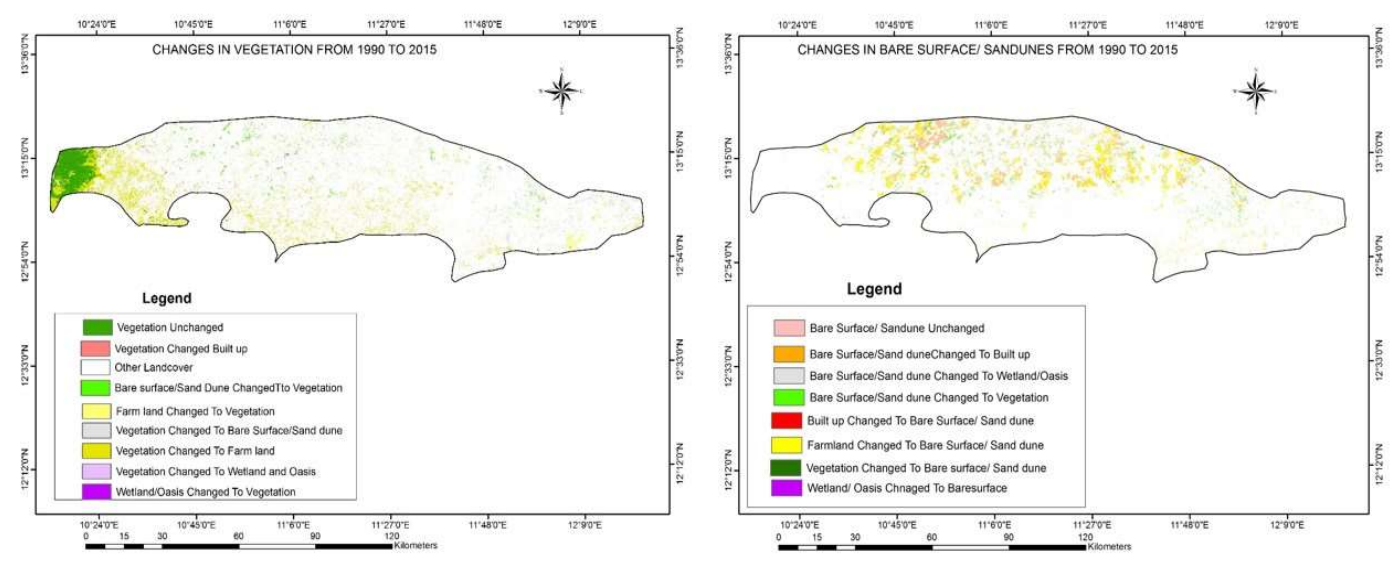

Figure 6: Land cover conversion maps (Vegetation and Sand dune transformations from 1990 to 2015) 
Table 3: Land cover conversions in Yusufari and Yunusari LGAs from 1990 to 2015

\begin{tabular}{|c|c|}
\hline Land cover conversions & Area (ha) \\
\hline Vegetation to Farmland & 62,411 \\
\hline Vegetation to Wetland and Oasis & 6,432 \\
\hline Vegetation Unchanged & 21,783 \\
\hline Vegetation to Bare/Sand dunes & 1,013 \\
\hline Vegetation to Built-Up & 394 \\
\hline Wetland and Oasis to Farmland & 21,922 \\
\hline Wetland and Oasis Unchanged & 33,142 \\
\hline Wetland and Oasis to Vegetation & 996 \\
\hline Wetland and Oasis to Bare/Sand dunes & 309 \\
\hline Wetland and Oasis to Built-Up & 163 \\
\hline Farmland Unchanged & 519,371 \\
\hline Farmland to Wetland and Oasis & 7,143 \\
\hline Farmland to Vegetation & 5,265 \\
\hline Farmland to Bare/Sand dunes & 54,455 \\
\hline Farmland to Built-Up & 4,624 \\
\hline Bare/Sand dunes to Farmland & 17,270 \\
\hline Bare/Sand dunes to Wetland and Oasis & 69 \\
\hline Bare/Sand dunes to Vegetation & 72 \\
\hline Bare/Sand Dunes Unchanged & 13,656 \\
\hline Bare/Sand Dunes to Built-Up & 291 \\
\hline Built Up to farmland & 61 \\
\hline Built to Wetland and Oasis & 39 \\
\hline Built Up to Bare/Sand dunes & 0.2 \\
\hline Built Up Unchanged & 2,419 \\
\hline Total & 773,298 \\
\hline
\end{tabular}

\subsection{Relationship of land cover conversions and climate parameters between 1990 and} 2015

We observed that the rainfall pattern in the study area changed from a total annual rainfall of $250 \mathrm{~mm}-350 \mathrm{~mm}$ from 1980-1993 to $340 \mathrm{~mm}-641 \mathrm{~mm}$ from 1994 to 2015 (Figure 7). Decreasing annual rainfall and increasing annual temperature trends in the study area was subsequently reversed to an increase in rainfall and lower temperatures especially in 1994, 2005, 2012 and 2014. This trend of climate parameters compared with the rate of desertification during this period should have implied positive feedback for afforestation in the study area. 


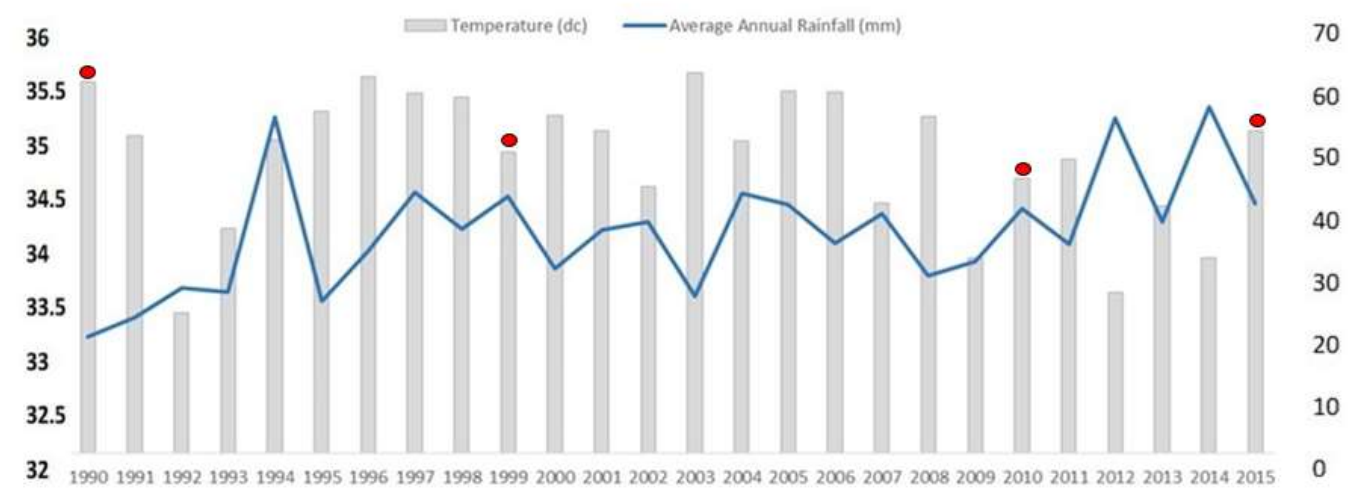

Figure 7: Average annual rainfall amounts and mean temperature over the study area (circled red: corresponding years analysed with remote sensing data)

Data Source: Nigerian Meteorological Agency (NIMET)

A statistical analysis of climate change and desertification indicators (using simple linear regression modelling) also suggests that over the study period (1990-2015), there was weak or no relationship or association between climate change indicators (namely increase in average annual rainfall amounts and decrease in mean temperature of the study area) and desertification indicators (namely declining vegetation, increasing sand dune formation and receding oasis and wetlands) (Figure 8a-e). Decrease in mean annual temperature had weak or no relationships with desertification trends represented by land cover/land use indicators like decreasing vegetation cover, intensified sand dune development and shrinking oasis and wetlands (Figure 8a, 8c and 8e). Results from this study also suggests that there is weak or no relationship between increase in average annual rainfall amount and shrinking oasis and wetlands (Figure 8f). 


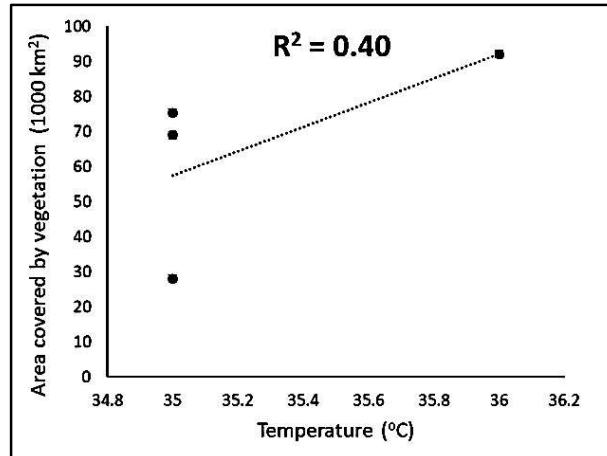

a. Relationship between temperature variability and vegetation loss

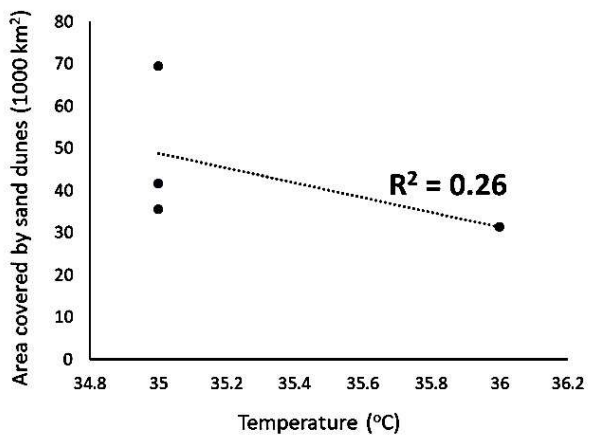

c. Relationship between temperature variability and sand dune formation

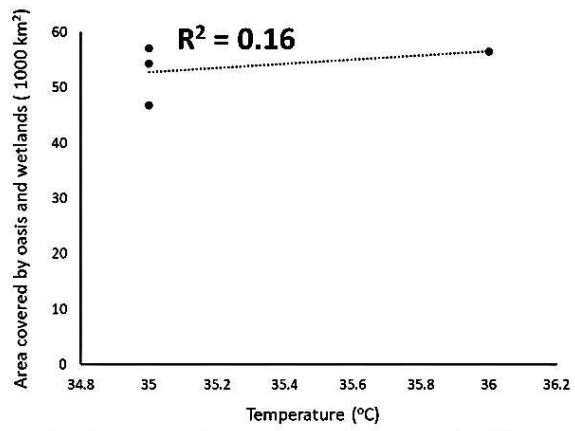

e. Relationship between temperature variability and oasis/wetland recession

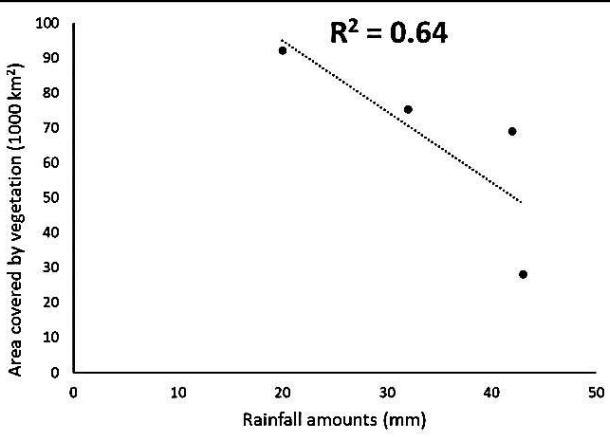

b. Relationship between rainfall variability and vegetation loss

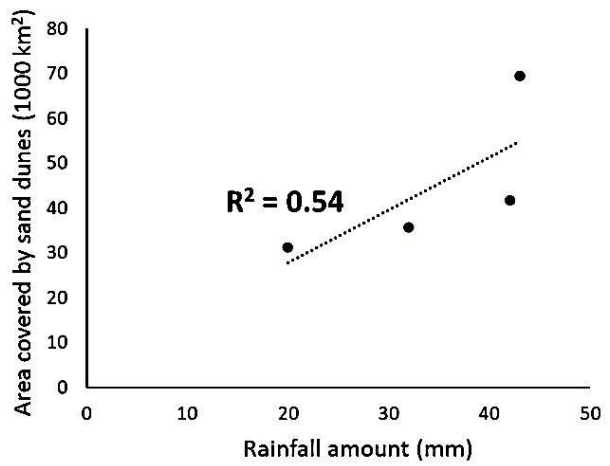

d. Relationship between rainfall variability and sand dune formation

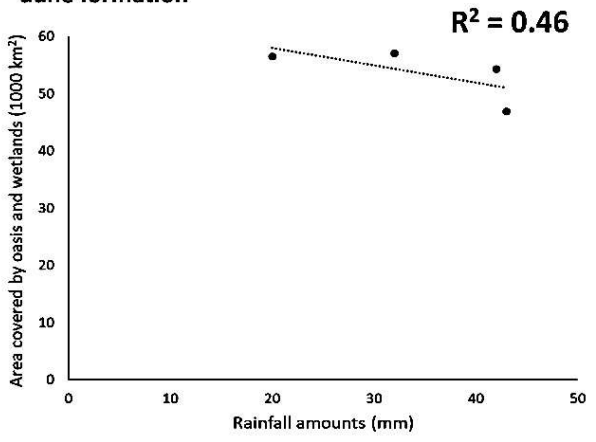

f. Relationship between rainfall variability and oasis/wetland recession

Figure 8: Relationship between desertification indicators and climate variables.

\subsection{Land cover probabilistic projections for 2030 and 2045}

Having observed past land-use conversions, the land-cover change between 2010 and 2015 was used to project future probabilistic land cover conversion (2030 and 2045). This is based on the assumption that management and socio-economic practices remain the same (i.e. business as usual scenario). The probability that the land cover indicators sensitive to desertification in the study area will become desert by 2030 is very low with a prospect value of 0.13 for farmland areas, a value of 0.10 for vegetated areas and 0.03 for oasis and wetland areas (see figure 9). Although in the second projection for the year 2045, the likelihood that most of the farmlands might be converted to deserts increased to 0.18 . The probability for most of the vegetated areas to be converted to sand dunes increased to 0.14 , while that for oasis and wetland increased to 0.12 . 


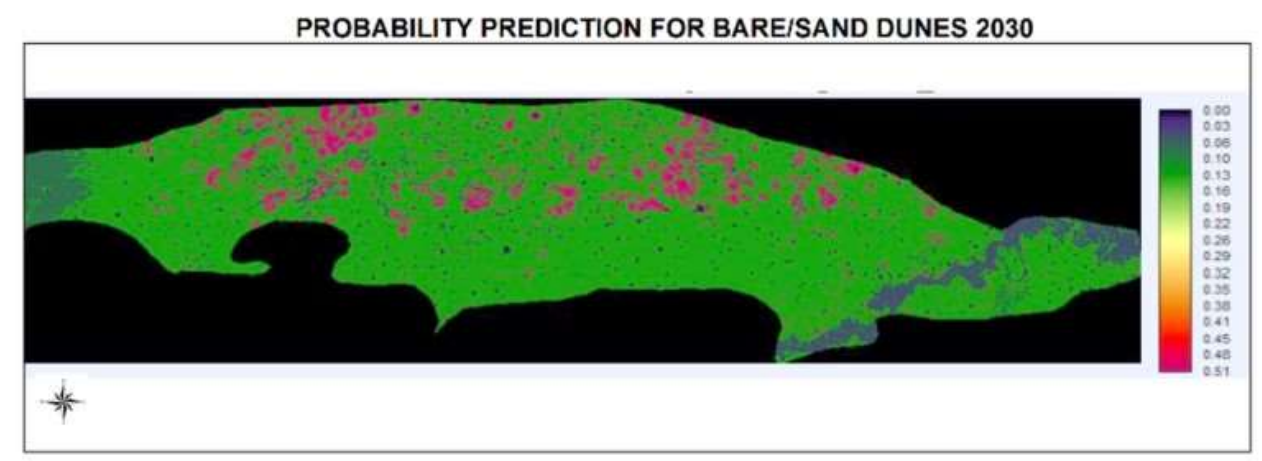

PROBABILITY PREDICTION FOR BARE/SAND DUNES 2045

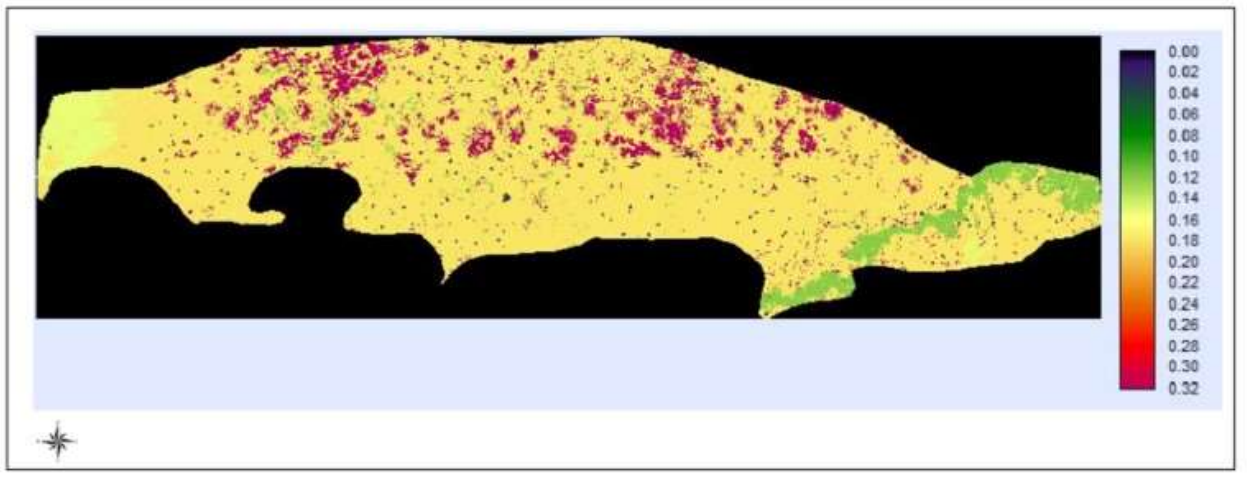

Figure 9: Probabilistic projections of sand dune in Yusufari and Yunusari

\section{Discussion}

\subsection{Land cover changes from 1990 to 2015}

The results depict major land cover changes over the 25 years study period. The Land cover start year (1990) coincides with the period Yobe State and more LGAs were created under the Military administration of former Head of State, General Babangida. This period was characterized by a low concentration of built-up areas in the study area, as also revealed in our land cover map. The areas classified as buildings and tarmacs subsequent years shows a consistent progression. The rate of built-up expansion however slowed down between 2010 and 2015. This can be attributed to many factors including desertification, insecurity and emigrations (i.e. the Boko Haram insurgency/conflicts), and other associated socio-economic challenges at this time. Although the reverse was the case for vegetation, with a consistent throughout the time slices examined especially between 2010 to 2015 (Table 1, Figure 3 and Figure 4). This period coincides with the years of security challenges in the State. The security situations might have led to a neglect of the building sector, with the security issues receiving the most attention. The massive reduction in vegetation cover over this same period is not unexpected as poor residents will depend on the environment for their survival. This is in line with observations from other studies by $[5,32]$, also reporting a decrease in vegetation in Yobe State in the recent past.

A similar pattern of decline was observed for the wetland and oasis land cover class. Looking at the available climate records (from the Nigeria Meteorological AgencyNIMET), this is attributable to a slight increase in rainfall and decrease in temperature at the period immediately preceding the year 2000 time point i.e. 1999 (see Figure 6 and Figure 7). This is in line with reports by Gadzama \& Ayuba, [12], which also observed a drastic reduction and shrinking of wetlands and water bodies over the same periods, which they attributed to rainfall fluctuations, as well as over-exploitation of surface water and 
groundwater for irrigation farming purposes. Continuity of this trend may result in further reduction of ground and surface water, as well as a general deterioration of water quality.

Conversely, farmland remains the dominant land cover in the study area with a consistent increase throughout the study period (see Figure 4, Figure 5 and Table 2). This finding also corresponds with results from other studies [5, 32]. Musa, [5] particularly asserted that intensified agricultural activities are the major factor influencing and aggravating desertification in the study area.

Another significant advancement is in the sand dune and bare areas. Rising from only $4.1 \%$ of the total land area in 1990 to $4.6 \%$ in ten years (2000), further rising to $5.4 \%$ in another 10 years (2010) and surprisingly, the progression in sand dunes over the next five years (2010-2015) increased to about 9\% of the total landmass. Elijah et al., [34] also reported a drastic increase in sand dunes in the study area between 2010 and 2013 based on satellite data analysis. Cumulatively, in our study, the coverage of sand dunes and bare areas over the 25 years study period has more than doubled from the start year. At this estimated rate, it can be inferred that sand dunes may cover about $20 \%$ of the landmass by the year 2040. This implies that up to 130, 000 ha of land might become desert if socioeconomic activities and management practices remain the same and if current no policy framework persists. On average, our results reveal that sand dune is progressing at a mean annual rate of 1, 524 ha (about $15.2 \mathrm{~km}^{2}$ ) in the study area. This corresponds with findings by other scientists and organizations putting the annual estimated progression rate of desertification in the Sahara region at about 0.6 to $35 \mathrm{~km}$ per year $[14,58]$. The Federal Ministry of Environment [15] similarly reported that between the period of 1976/1978 and 1993/1995 (19 years period), sand dunes increased by approximately 17\% from 820 to $4,830 \mathrm{~km}^{2}$.

While there is a consensus on the continuous advancement of dunes in the study area, different studies attributed the phenomenon to a variety of plausible causative factors. Amadi et al., [32] reported that the main cause of desertification in Yobe State, Nigeria is high solar radiation and pore space reduction in soils as a result of the trampling effects of overgrazing. They however also attributed the aggravation of dune formation to insufficient rainfall and wind erosion. This calls for intensification of government efforts aimed at reducing the spread and escalation of desertification in Nigeria. Though over the years, there have been combined efforts by international and regional organizations in combating desertification globally. According to the United Nations (UN) reports, an estimated US $\$ 45$ billion is disbursed annually in missions and programs to fight desertification [59]. There are also local and international efforts in Nigeria. In 1994, Nigeria signed the convention of the UN to combat desertification. There exist a wide range of national efforts to combat desertification in the areas affected in Nigeria. This includes Arid Zone Afforestation Project (AZAP), the River Basin Development Authorities (RBDA, Federal and State Environmental Protection Agency (FEPA / SEPA), and recently the famous Great Green Wall Project [11]. Although reports have shown promising progress in combating desertification in many frontline States e.g. Sokoto, Katsina and Kano States [12], the appraisals that suggest such progress was in 1989. There is a need to update these progress reports using ground data and remote sensing technologies. A general estimate of vegetative cover provided by FORMECU in 1990 gave critical evidence of the serious vegetation changes and biodiversity loss, particularly in the northern part of the country. This provided insights and forewarnings on the increasing magnitude of the problems of desertification in Nigeria. This is consistent with recent studies, as well as the results of our remote-sensing based analysis. 


\subsection{Land cover conversions from 1990 to 2015}

The most significant land cover conversions under the study period and study area was from vegetated land to farmlands (Figure 6 and Table 3). Implying that locals convert some of the few vegetated lands to farmlands for crop cultivation, because they are perceived to be more fertile. Very small land area (394 ha) vegetated land was converted to built-up. This is because vegetation often serves as a shelter, carbon sink, sources of oxygen, and windbreak around areas of human habitation in most settlements in Sub Sahara Africa [60]. Most residents therefore do not remove trees during residential constructions.

Wetland and oasis have remained largely unchanged from 1990 to 2015 (about 331, 412 ha), however about 996 ha of wetlands and oasis were converted to vegetation. This might have been a product of natural regrowth as a result of favourable growth conditions (i.e. availability of water) or drying water bodies replaced by vegetation. Surprisingly, 17, 270 ha of sand dunes were converted to farmlands. This is in line with our field observations in 2016, as we observed farming efforts on degraded lands. Also, according to Musa, [5], locals still make efforts to cultivate less fertile lands/sand dunes as a result of poverty. This finding aligns with assertions by other scientists who claim that populations inhabiting degraded lands in developing nations live in abject poverty and depend largely on the natural environments [61]. Very small land area (0.2 ha) of land was converted from built-up to sand dunes. This suggests that there is an abandonment of settlements and migration as a result of desertification and associated security challenges in the Yusufari and Yunusari area of Yobe state Nigeria.

Within the 25-year study period, farmlands remained consistent, likewise major land areas covered by wetlands and oasis did not undergo a change in nature or characteristics (Figure 6 and Table 3). In line with previous findings in the region, a significant proportion of land was found to have been converted from farmland to sand dunes (54, 455 ha). Musa, [5] reported that intensified agricultural activities are the major cause and escalator of desertification in the study area. Amadi et al., [32], and Mansur \& Ismail, [33], also reported that sand dune advancements was more rampant across large expanse of agricultural farmlands and grazing lands. On a positive note, significant portions of sand dunes were converted to vegetation (72 ha), indicative of the progress of the various international, national, local, and individual afforestation efforts. On the other hand, larger land area of vegetation (1,013 ha) were converted to sand dunes, indicating greater deforestation compared to afforestation. This partly might have been associated with the reliance of local communities in Nigeria on biomass as cooking energy. The vegetated portion of the area is the major source of supply of food, fuel and income generation for the rural populace. The inhabitants of the Yusufari and Yunusari communities mostly engage in farming, hunting, nomadic cattle rearing and fishing for their livelihoods. Most of these economic activities depend on the surrounding vegetated environment and landscapes. This further accelerates environmental degradation, food insecurity and poverty [61 - 63]. Furthermore, lack of strict and enforceable land-use guidelines, as well as the low impact of previous international, national and local desert mitigation efforts also play a role in Nigeria's worsening desertification [16]. Other factors contributing to the exacerbation of desertification include weak participation of 
different stakeholders in the decision-making and decision-taking value chains, poor regulation enforcement, as well as low budget allocation and financial commitment towards combating desertification and other environmental-related disasters [12]. If not properly addressed, it can lead to further loss in biodiversity and species extinction, reduced agricultural yields, higher unemployment and rural poverty rates, as well as rise in social vices and civil conflicts (e.g. kidnapping, armed robbery, religious extremism, insurgency, land/territory grabbing etc) as reported in similar regions of the wolrd [15] and currently escalating in the Yunusari and Yusufari and other similar desert regions in Nigeria.

\subsection{Relationship of land cover conversions and climate parameters between 1990 and 2015}

The meteorological records of the study area show a decline in temperature and increase in annual rainfall in 1994, 2005, 2012 and 2014 (Figure 7). This trend of climate parameters compared with the rate of desertification during the time stamps we analysed should have implied positive feedback for afforestation in the study area. However, the reverse was the case as there was further expansion of sand dune features. Expected reduced air and soil dryness from reduced temperature and increase rainfall did not translate to favourable conditions for natural vegetation regrowth. Likewise, the statistical analysis of climate parameters and desertification indicators also suggests that there was weak or no relationship or association between climate change indicators (Figure 8). Decrease in mean annual temperature had weak or no relationships with desertification trends represented by land cover/land use indicators (Figure 8a, 8c and 8e). Even though the high r2 values obtained in Figure $8 \mathrm{~b}$ and $8 \mathrm{~d}$ may want to suggest that increase in average annual rainfall amount could be responsible for vegetation loss and advancement of bare surfaces/sand dunes under the arid conditions in the study area, in reality, this defies logic and is geomorphological unlikely or almost impossible from a geological point of view. While increase in average annual rainfall amount could be associated with vegetation loss and increase in bare surfaces/sand dunes features in wetter regions with potentially higher run-offs and greater risks of rainfall-induced erosion, in arid regions with low rainfall, little or no run-offs and significantly high evapotranspiration rates, this is unlikely to be the case.

Our statistical results also suggest weak or no relationship between increase in average annual rainfall amount and shrinking oasis and wetlands (Figure 8f). Actually, the reverse should be expected geologically or geomorphological i.e. increase in average rainfall amount should recharge and extend the coverage of oasis and wetlands and not shrink it. Going by the observed mismatch between the result of the statistical analysis and prevailing geological and geomorphological understandings, we may want to infer that climate change is not responsible for desertification in the study area and region. Although we used only four stamps within the 25-year time span under study for the repression, the climatic records reveal a general rise in rainfall within the entire 25-year period . Both the visual comparison of climate records with indicators of desertification (i.e. reduced vegetation, expansion of sand dune features and drying oasis/wetlands) over the study period (Figure 7), and the simple linear regression models investigating potential climatic parameters for explaining desertification indicators in the study area (Figure 8) suggest that climatic parameters do not explain or account for desertification in the study area. This also aligns with claims by Musa [5] that desertification in Yobe State is not due to climatic elements alone but also due to human factors such as over-cultivation, overgrazing, deforestation, tree felling, poor land use, etc. According to Gadzama \& Ayuba, [12] and Apata et al., [16] desertification may also be influenced by other factors such as lack of 
local awareness, absence of a political will and paucity of funding to support land reclamation and anti-desertification programs. It is important to also note that desertification can be further worsened by poverty, population increase and deliberate government policies which also puts immense burden and pressure on fragile landscape and ecosystem [62] especially under climate change. In view of highlighted remote sensing results, visualized climate records, statistical analysis and previous publications on the subject matter, it can be concluded that desertification in the study area is less a function of climate change and more a product of human activities driven by poverty and population growth. In the light of poverty and population growth issues in Nigeria, McCormick [64] brought to focus that environmental problems do not only result from unsustainable development initiatives and implementations alone, but also from the rapid increase in population and poverty. This often led to rural agriculturalists abandoning resource management practices and over-exploiting environmental resources accessible to them for sustenance of livelihoods.

\subsection{Land cover probabilistic projections for 2030 and 2045}

The probabilistic land cover projections of the area show high likelihood of farmlands converted to sand dunes by 2030, and very low threshold of increased desertification within the vegetated, oasis and wetland areas (see figure 7). However, projections for 2045 shows increased probability of farmlands converted to sand dunes, and likewise vegetated areas, oasis and wetland becoming sand dunes.

These probabilistic projections raise the need for more effective intervention programs. In general, despite several intervention efforts in the past (from United Nations Environmental Programme-UNEP, Arid Zone Afforestation Project-AZAP, the River Basin Development Authorities-RBDA, Federal/State Environmental Protection Agency-FEPA/SEPA, Great Green Wall Project etc.), our findings and other reports show that desert encroachment has only increased in the study area, and is gradually reaching proportions that it should be considered a major ecological disaster and a threat to the nation's economy [61 $-66]$.

\section{Conclusions}

The three major indicators of increasing aridity namely: expansion of sand dunes, declining vegetation cover, and shrinking of wetlands and water bodies has intensified in the study area over the 25-year study period analyzed. The coverage of sand dunes has more than doubled from the start year. While vegetation, wetlands, and water bodies have experienced a significant decline. At this rate, it can be inferred that sand dunes may cover about $20 \%$ of the present landmass of the study area by the year 2040 . This implies that up to 130,000 ha of land might become sand dunes if the socio-economic activities and management practices remain as usual and if the current no-policy framework situation persists. Given the highlighted remote sensing results, reconciled climate records, statistical analysis and previous literature, it can be inferred that desertification in the study area is less a product of climate change and more a function of human activities and factors e.g. unsustainable agricultural practices such as over-cropping of marginal or fragile land, overgrazing, poverty, population pressure and poor government policies. Evidence from ground-truthing exercise revealed that large hectares of land have been allocated to politicians, retired civil servants and wealthy individuals. Existing vegetation on such lands is expected to be cleared and converted to farmlands or built-ups. Aggressive policies (with penalties) aimed at conserving such lands and mitigating the current desertification trends are therefore needed as a matter of urgency. More precise and frequent re- 
motely sensed data, as well as ground-based inventories to establish the extents of desertification, is needed continually. Previous efforts at tackling deforestation in the study area have not yielded significant results. Further community engagement and participation in the afforestation and reforestation projects and poverty alleviation programs (diversification) will therefore be required. In doing this, choices of native species that will enhance biodiversity on the one hand, and also take care of long-term local food, grazing reserve and energy security needs should be prioritized. Examples of such previously identified woody species include Acacia senegal, Acacia nilotica, Balanite aegyptiaca, Callotropis procera, Azadirachta indica and Jatropha curcas. Suitable grass species may include Guinea grass, Pennisetum spp, Elephant grass etc. To mitigate the pressure on the fragile vegetation in the study area, more efforts should be directed towards the establishment of woodlots, shelterbelts and grazing reserves. The adoption of agroforestry and sustainable energy saving stoves will also help meet energy security needs and reduce pressures on the already sparse vegetation systems [67]. The adoption of sustainable energy saving stoves by women (e.g Sosai Energy) is particularly crucial in reducing fuelwood consumption and combating desertification, as the role of women is vital in sustainable environmental management. The study area and Sahel region as a whole should be delineated as an emergency disaster zone with intervention projects assigned strong priority in government budgeting cycles. This is because the area is one of the nation's food basket. Advancement of sand dune features is therefore a threat to national food security and local rural sustainability in these areas. A downgrading of status from being a major agricultural producer to a region where agriculture is only a means of survival is imminent. Growing insurgency and armed conflicts in the Sahel region, as well as migration and abandonment of settlements are significant consequences that accompany increase in sand dune development. They should therefore be classified as an emergency situation deserving urgent national action. We also strongly recommend a further studies, with very comprehensive annual assessments of climatic, socio-economic and land cover indicators using advanced statistical approaches to further understand and highlight local causes of desertification in the desertification front line states in Nigeria and other parts of Sub-Sahara Africa. If not properly addressed, desertification can lead to further loss in biodiversity and species extinction, reduced agricultural yields, higher unemployment and rural poverty rates, as well as rise in social vices and civil conflicts (e.g. kidnapping, armed robbery, religious extremism, insurgency, land/territory grabbing etc) as it is currently intensifying in the Yunusari and Yusufari and other similar desert regions in Nigeria.

Author Contributions: Conceptualization, E.S.I., B.A. and S.B.S; methodology, E.S.I., J.B. and B.A.; software, E.S.I.; validation, E.S.I., J.B. and B.A.; formal analysis, E.S.I., J.B., O.T.A and B.A.; investigation, E.S.I., J.B., M.I.M., H.A.S. and B.A.; resources, B.A, B.A.D and S.B.S.; data curation, E.S.I., J.B., M.I.M: and B.A.; writing-original draft preparation, E.S.I; writing-review and editing, E.S.I., J.B., O.T.A, B.A.D, M.I.M, H.A.S, S.B.S and B.A.; visualization, E.S.I., J.B., O.T.A, and B.A.D.; supervision, H.A.S, S.B.S and B.A..; project administration, B.A. and S.B.S. All authors have read and agreed to the published version of the manuscript.

Funding: This research received no external funding

Conflicts of Interest: The authors declare no conflict of interest. 


\section{References}

In the text, reference numbers should be placed in square brackets [ ] and placed before the punctuation; for example [1], [1-3] or $[1,3]$. For embedded citations in the text with pagination, use both parentheses and brackets to indicate the reference number and page numbers; for example [5] (p. 10), or [6] (pp. 101-105).

1. Bauer, S. The Role of Science in the Global Governance of Desertification. The J. of Envt E Dev. 2009, 18, 3; DOI: https://doi.org/10.1177/1070496509338405.

2. Johnson, P.M. Governing global desertification: linking environmental degradation, poverty and participation. Ashgate Publishing. ISBN:978-0-7546-4359-3. 2016 (ed.). Available online: http://books.google.com/books?id=da6vhzHEpf0C (Accessed on 15th March 2019).

3. Holtz, U. Implementing the United Nations Convention to Combat Desertification from a parliamentary point of view Critical assessment and challenges ahead. 2007. Available online: https://nanopdf.com/download/implementing-theunited-nations-convention-to-combat_pdf (Accessed on 15th March 2019).

4. Cornet, A. Desertification and its relationship to the environment and development: A problem that affects us all. In: Ministère des Affaires étrangères/adpf, Johannesburg. World Summit on Sustainable Development. 2002. What is at stake? The contribution of scientists to the debate: 91-125. 2002. Available online: http://www.csf-desertification.org/bibliotheque/item/desertification-and-its-relationship-to-the-environment-and-development

5. Musa, J. An Assessment of the Effects of Desertification in Yobe State, Nigeria. Con. J. Envtal Stds. 2012, 72-87. Available online: https://citeseerx.ist.psu.edu/viewdoc/download?doi=10.1.1.916.9869\&rep=rep1\&type=pdf (Accessed on $24^{\text {th }}$ March 2019).

6. Lamprey, H.F. Report on the desert encroachment reconnaissance in northern Sudan, 21 October - November 1975. UNESCO/UNEP. Paris/Nairobi. republished in Desertification Bulletin 17. 1988. pp 1-7.

7. Mandal, R.B. “Regional Dynamics of the Sahel”. In: Mundal (eds.), Patterns of Regional Geography: An International Perspective, Volume 3, World regions. New Delhi, India, Concept Publishing Company, 1990, pp.145. Available online: https://www.amazon.com/Patterns-regional-geography-international-perspective/dp/8170222893 (Accessed on $13^{\text {th }}$ March 2019).

8. Kemp, D.D. The Environment Dictionary, London and New York, Routledge. 1998, pp. 96. Available online: https://www.routledge.com/The-Environment-Dictionary/Kemp/p/book/9780415127530 (Accessed on 15th March 2019).

9. Ci, L.; Yang, X. Desertification and Its Control in China. Springer. 2010. p. 10.ISBN 978-7-04-025797- 7. Available online: https://link.springer.com/book/10.1007/978-3-642-01869-5 (Accessed on 13 ${ }^{\text {th }}$ March 2019).

10. Olagunju, E. T. Drought, desertification and the Nigerian environment: A review. J. of Eco. Nat. Environ. 2015, 7, 7, 196-209. DOI: http://doi:10.5897/JENE2015.0523.

11. Gadzama, N.M.; Ayuba, H. K. On major environmental problem of desertification in Northern Nigeria with sustainable efforts to managing it. World J. of Sci., Tech. and Sust. Devt. 2016. 13, 1, 18-30. DOI; http://10.1108/WJSTSD-06-2015-0035.

12. Jaiyeoba, I. A. Environment in Africa Atlases: Nigeria. Les Edition J. A. Paris. 2002. pp. 22-123.

13. Tiffen, M.; Mortimore, M. Questioning desertification in dryland sub-Saharan Africa. Nat. Res. Forum, 2002. 26, 218-233; DOI; https://doi.org/10.1111/0165-0203.t01-1-00023.

14. Federal Ministry of Environment of Nigeria. National Action Plan to combat desertification. 2009.

15. Abahussain, A.A.; Abdu, A.; Al-Zubari, W.K.; El-Deen, N.A.; Abdul-Raheem, M. Desertification in the Arab Region: analysis of current status and trends. J. Arid Environ. 2002, 51, 4, 521-545. DOI; https://doi.org/10.1006/jare.2002.0975

16. Apata, T.G.; Folayan, A.; Apata, O.M.; Akinlua, J. "The Economic Role of Nigeria's Subsistence Agriculture in the Transition Process: Implications for Rural Development," 85th Annual Conference, April 18-20, 2011, Warwick University, Coventry, UK 108942, Agricultural Economics Society. DOI: 10.22004/ag.econ.108942.

17. Lal, R. Land degradation and pedological processes in a changing climate. Soil Degrad. Proc. 2008, 12, 315-325. Available online: https://www.yumpu.com/en/document/view/49060726/land-degradation-and-pedological-processes-in-a-changing-climate

18. Hein, L.; de Ridder, N.; Hiernaux, P.; Leemans, R.; de Wit, A.; Schaepman, M. Desertification in the Sahel: Towards better accounting for ecosystem dynamics in the interpretation of remote sensing images. J. Arid Environ. 2011, 75, 1164-1172; DOI; https://doi.org/10.1016/j.jaridenv.2011.05.002.

19. Glenn, E.; Stafford, S.M.; Squires, V. On our failure to control desertification: Implications for global change issues, and a research agenda for the future. Environ. Sci. Policy, 1998. 1, 71-78. DOI; https://doi.org/10.1016/S1462-9011(98)00007-0.

20. Veron, S.; Paruelo, J.; Oesterheld, M. Assessing desertification. J. Arid Environ, 2006, 66, 751-763. DOI:10.1016/j.jaridenv.2006.01.021.

21. Hill, J.; Stellmes, M.; Udelhoven, T.; Röder, A.; Sommer, S. Mediterranean desertification and land degradation: Mapping related land use change syndromes based on satellite observations. Glob. Planet. Chang., 2008, 64, 146-157. DOI; https://doi.org/10.1016/j.gloplacha.2008.10.005.

22. Symeonakis, E.; Drake, N. Monitoring desertification and land degradation over sub-Saharan Africa. Int. J. Remote Sens. 2004. 25, 573-592. DOI; https://doi.org/10.1080/0143116031000095998. 
23. Bai, Z.G.; Dent, D.L.; Olsson, L.; Schaepman, M.E. Proxy global assessment of land degradation. Soil Use Manag. 2008, 24, 223-234; DOI: https://doi.org/10.1111/j.1475-2743.2008.00169.x.

24. Collado, A.D.; Chuvieco, E.; Camarasa. Satellite Remote Sensing Analysis to Monitor Desertification Processes in the CropRangeland Boundary of Argentina. J. of Arid Environ. 2002 52: 121-133; DOI:10.1006/jare.2001.0980, http://www.idealibrary.com.

25. Li, j.; Yang, X.; Jin, Y.; Yang, Z.; Huang, W.; Zhao, L.; Gao, T.; Yu, H.; Ma, H.; Qin, Z.; Xu, B. Monitoring and Analysis of Grassland Desertification Dynamics using Landsat Images in Ningxia. Remote Sens. of Environ. 2013, 138. 13-26; DOI: https://doi.org/10.1016/j.rse.2013.07.010.

26. Yang, Y.; Wand, Z.; Li, j.; Gang, C.; Zhang, Y.; Odeh, I.; Qi, J. Comparative assessment of grassland degradation dynamics in response to climate change variation and human activities in China, Mongolia, Pakistan and Uzbekistan from 2000 to 2013. J. of Arid Environ, 2016. 135, 164-172; DOI: https://doi.org/10.1016/j.jaridenv.2016.09.004.

27. Owusu, A.; Cervo, G.; Luzzadder-Beach, S. Analysis of Desertification in the Upper East Region (UER) of Ghana Using Remote Sensing, Field Study, and Local Knowledge. Int. J. for Geo. Infor. and Geo-vis. Cart. 2013, 48, 1, 22-37 6; DOI: http://doi:10.3138/carto.48.1.1065.

28. Ahmadi, H. Iranian model of desertification potential assessment (IMDPA), Faculty of Natural Resources, University of Tehran, Iran, 2004. pp 268.

29. Rasmy, M.; Gad, A.; Abdelsalam, H.; Siwailam, M. A dynamic simulation model of desertification in Egypt. The Egyptian J. of Remote Sens. and Space Sci. 2010. 13, 2, 101-111; DOI: https://doi.org/10.1016/j.ejrs.2010.03.001.

30. Silakhori, I.; Ownegh, M.; Sadoddin, A.S. Assessment of desertification risk in Sabzevar using MICD. Crisis Manage. Res. J. 2014, 91, 89-99; DOI: 20.1001.1.23453915.1393.3.1.8.9.

31. Akbari, M.; Ownegh, M.; Asgari, H.R.; Sadoddin. A.; Khosravi, H. Desertification risk assessment and management program. Global J. Environ. Sci. Manage. 2016, 2, 4, 365-380; DOI: http://doi:10.22034/gjesm.2016.02.04.006.

32. Amadi, D. C. A.; Maiguru, A.; Zaku, S.; Yakubu, T. Pattern of Desertification in Yobe State of Nigeria. J. of Environ. Sci., Toxicology and Food Tech. 2013, 5, 5, 12-16. DOI:10.9790/2402-0551216.

33. Mansur, M. A.; Ismail, M. H. GIS-Based Quantitative Assessment of Desertification in Kebbi State Nigeria. Proceedings of the International Conference on Sustainable Forest Development in view of Climate Change (SFDCC2016) 8-11th August 2016, Hotel Bangi-Putrajaya, Malaysia. Available online: http://a.xueshu.baidu.com/usercenter/paper/show?paperid=43261f9db8e84b709b16763ce6e7caa9 (Accessed on 30 ${ }^{\text {th }}$ June 2020)

34. Elijah E.; Ikusemoran M.; Nyanganji K.J.; Mshelisa H. U. Detecting and Monitoring Desertification Indicators in Yobe State, Nigeria. J. of Envt., Iss and Agric in Develop. Count. 2017, 9, 1, 2141-2731. Available online: https://www.researchgate.net/publication/333561428_Detecting_and_Monitoring_Desertification_Indicators_in_Yobe_State_Nigeria(Accessed on 23 ${ }^{\text {th }}$ June 2020)

35. Titiola, K. Environment and Sustainable Agricultural Development in Nigeria. Lagos: Flaghan Printing Press, 1998. Available online: https://citeseerx.ist.psu.edu/viewdoc/download?doi=10.1.1.535.4291\&rep=rep1\&type=pdf (Accessed on 30th June 2020).

36. Nigerian Bureau of Statistics, 2010. Annual Abstract of Statistics 2010. Federal Republic of Nigeria. Available online: http://ghdx.healthdata.org/record/nigeria-annual-abstract-statistics-2010 (Accessed on 30 ${ }^{\text {th }}$ June 2020).

37. Nigerian Bureau of Statistics, 2012. Annual Abstract of Statistics 2012. Federal Republic of Nigeria, Available online:https://www.nigerianstat.gov.ng/pdfuploads/annual_abstract_2012.pdf (Accessed on 30 th June 2020).

38. Burke, M.; Lobell, D.B. Satellite-based assessment of yield variation and its determinants in smallholder African systems. Proceedings of the National Academy of Sciences of the United States of America, 2017, 114, 2189-2194. Available online: DOI:10.1073/pnas.1616919114.

39. Ibrahim, E. S.; Rufin, P.; Nill, L.; Kamali, B.; Nendel, C.; Hostert, P. Mapping Crop Types and Cropping Systems in Nigeria with Sentinel-2 Imagery. Remote Sens. 2021. 13, 17; DOI: 10.3390/rs13173523.

40. Potere, D.; Schneider, A.; Angel, S.; Civco, D. Mapping Urban Areas on a Global Scale: Which of the Eight Maps Now Available Is More Accurate? Int. J. Remote Sens. 2009, 30, 6531-6558. DOI: 10.1080/01431160903121134.

41. Trianni, G.; Lisini, G.; Angiuli E.; Moreno, E. A.; Dondi P.; Gaggia, A.; Gamba P. Scaling up to National/Regional Urban Extent Mapping Using Landsat Data. J. of Sel. Topics in Applied Earth Obs. and Remote Sens. 2015, 8,7, 3710-3719; DOI: 10.1109/JSTARS.2015.2398032.

42. Forget, Y.; Linard, C.; Gilbert, M. Supervised Classification of Built-Up Areas in Sub-Saharan African Cities Using Landsat Imagery and Open-Street-Map. Remote Sens. 2018, 10, 7, 1145; ISSN 2072-4292. DOI: https://www.mdpi.com/20724292/10/7/1145.

43. Forget, Y.; Shimoni, M.; Gilbert, M.; Linard, C. Mapping 20 Years of Urban Expansion in 45 Urban Areas of Sub-Saharan Africa. Remote Sens. 2021, 13, 3, 525, DOI; https://www.mdpi.com/2072-4292/13/3/525.

44. Bey, A.; Jetimane, J.; Lisboa, S.N.; Ribeiro, N.; Sitoe, A.; Meyfroidt, P. Mapping smallholder and large-scale cropland dynamics with a flexible classification system and pixel-based composites in an emerging frontier of Mozambique. Remote Sens. of Environ. 2020, 239, 111611. DOI: https://doi.org/10.1016/j.rse.2019.111611.

45. Erbek F. S.; Özkan, C.; Taberner M. Comparison of maximum likelihood classification method with supervised artificial neural network algorithms for land use activities. Int. J. of Remote Sens. 2004, 25, 9, 1733-1748; DOI: $10.1080 / 0143116031000150077$. 
46. Weih, R.C.; Riggan N.D. Object-based classification vs. pixel-based classification: comparative importance of multi-resolution imagery. Int. Arch. Photogramm. Remote Sens. Spat. Inf. Sci., 2010, 38. Available online; https://www.isprs.org/proceedings/xxxviii/4-c7/pdf/Weih_81.pdf.

47. Maulik U.; Chakraborty D. Remote sensing image classification: a survey of support-vector-machine-based advanced techniques. Trans. Geosci. Remote Sens. 2017, 5, 33-52; DOI: 10.1109/MGRS.2016.2641240

48. Qiu, C.; Schmitt, M.; Mou, L.; Ghamisi, P.; Zhu, X.X. Feature importance analysis for local climate zone classification using a residual convolutional neural network with multi-source datasets. Remote Sens. 2018, 10, 10, 1572; DOI: https://doi.org/10.3390/rs10101572

49. Richards, 2012

50. Olofsson, P.; Foody, G. M.; Stehman, S. V.; Woodcock, C. E. Making better use of accuracy data in land change studies: Estimating accuracy and area and quantifying uncertainty using stratified estimation. Remote Sens. of Environ. 2013, 129, 122-131. DOI; https://doi.org/10.1016/j.rse.2012.10.031.

51. Yang, X.; Zheng, X.Q.; Lv. L.N. A spatiotemporal model of land use change based on ant colony optimization, Markov chain and cellular automata. Ecol. Model, 2012, 233, 11-19; DOI; https://doi.org/10.1016/j.ecolmodel.2012.03.011.

52. Al sharif A.A.; Pradhan B. Monitoring and predicting land use change in Tripoli metropolitan city using an integrated markov chain and cellular automata models in GIS. Arabian J. Geosci., 2014, 7, 4291-4301; DOI 10.1007/s12517-013-1119-7

53. Losiri ,C.; Nagai, M.; Ninsawat, S.; Shrestha R.P. Modeling urban expansion in Bangkok metropolitan region using demographic-economic data through cellular automata-markov Chain and multi-layer perceptron-markov chain models. Sustainability, 2016. 8, 7, 686; DOI; https://doi.org/10.3390/su8070686.

54. Abdulla - AlKafy, M.D.; Nazmu,1 H.; Gangaraju, S.; Abdullah, A.; Nessar, U.; Abdullah, A.; Marium, A.; Golam, S. Cellular Automata approach in dynamic modelling of land cover changes using RapidEye images in Dhaka, Bangladesh. Environ. Chall. 2021, 4, 100084; DOI;https://doi.org/10.1016/j.envc.2021.100084.

55. Eastman J. R. IDRISI Selva Tutorial Manual Version 17, 2012. Clark University. Available online: http://uhulag.mendelu.cz/files/pagesdata/eng/gis/idrisi_selva_tutorial.pdf

56. Enoguanbhor, E.C.; Gollnow, F.; Nielsen, J.O.; Lakes, T.; Walker, B.B. Land Cover Change in the Abuja City-Region, Nigeria: Integrating GIS and Remotely Sensed Data to Support Land Use Planning. Sustainability, 2019, 11, 1313; DOI: https://doi.org/10.3390/su11051313.

57. Enoguanbhor, E.C.; Gollnow, F.; Walker, B.B.; Jonas O.N.; Tobia Lakes. Simulating Urban Land Expansion in the Context of Land Use Planning in the Abuja City-Region, Nigeria. Geo J. 2020. DOI; https://doi.org/10.1007/s10708-020-10317.

58. Gadzama, N.M. "Sustainable development in the arid zone of Nigeria". Monograph Series No. 1, Centre for Arid Zone Studies, University of Maiduguri Press, Maiduguri, 1995, pp 32.

59. United Nations Environmental Program (UNEP). Atlas of our Changing Environment. Nairobi: Division of Early Warning and Assessment (DEWA), UNEP, 2008. Available online: https://na.unep.net/atlas/datlas/sites/default/files/unepsiouxfalls/atlasbook_1135/Kenya_Screen_Intro.pdf (Accessed on 30 th June 2020).

60. Petersen, M.; Bergmann, C., Roden, P.; Nüsser, M. Contextualizing land-use and land-cover change with local knowledge: A case study from Pokot Central, Kenya. Land Degrad Dev. 2021, 32, 2992-3007; DOI: https://doi.org/10.1002/ldr.3961

61. Holtz, U. Implementing the United Nations Convention to Combat Desertification from a parliamentary point of view Critical assessment and challenges ahead. 2007. Available online: https://nanopdf.com/download/implementing-theunited-nations-convention-to-combat_pdf. (Accessed on $29^{\text {th }}$ June 2020).

62. Johnson, P.M. (ed.). Governing global desertification: linking environmental degradation, poverty and participation. Ashgate Publishing. 2006. ISBN:978-0-7546-4359-3. Available online:https://books.google.de/books/about/Governing_Global_Desertification.html?id=da6vhzHEpf0C\&redir_esc=y (Accessed on 30 ${ }^{\text {th }}$ June 2020).

63. Nwokoro, C.V; Chima, F.O. Impact of Environmental Degradation on Agricultural Production and Poverty in Rural Nigeria. American Int. J. of Contemporary Research, 2017, 7, 2.2162-139. https://www.semanticscholar.org/paper/Impact-of-Environmental-Degradation-on-Agricultural-Nwokoro-Chima/4bfeec90b749f146e9387905cd7ea95317d6142c.

64. McCormick J. Environmental Politics. In: Dunleavy P., Gamble A., Holliday I., Peele G. (eds) Developments in British Politics 4. Palgrave, London 1993. Available online: https://doi.org/10.1007/978-1-349-22802-7_12 (Accessed on 29th June 2020).

65. Medugu, N.I. Nigeria and the advancing Desert. Environmental Synergy World Press.com. 2009. Available online: https://environmentalsynergy.wordpress.com/2009/05/14/nigeria-and-the-advancing-desert/(Accessed on 29th June 2020).

66. Okoli, J.N; Ifeakor, A. C. An Overview of Climate Change and Food Security: Adaptation Strategies and Mitigation Measures in Nigeria. J. Educ. and Pract. 20145, 32. Available online: https://www.iiste.org/Journals/index.php/JEP/article/view/16708.

67. SREC. Projects: Sosai Renewable Energies Company. Available online: http://sosairen.org/projects.php Accessed on 6th February 2019) 